\title{
Production of Agri-Energy Crop Miscanthus gigantheus on Land Degraded by Power Industry: SWOT Analysis
}

\author{
Dragana Kalabić1, Gordana Dražić1*, Nikola Dražić1, Jela Ikanović \\ ${ }^{1}$ University Singidunum Faculty for Applied Ecology Futura, Belgrade Republic of Serbia \\ ${ }^{2}$ Belgrade University Faculty of Agriculture, Belgrade, Republic of Serbia
}

Received: 5 June 2018

Accepted: 24 July 2018

\begin{abstract}
The hypothesis that land degraded by activities in the Kolubara Mining Basin may be restored by production of agri-energy crop Miscanthus gigantheus in ecologically and economically sustainable manner was investigated. The characteristics of the arable soil in the zone of influence of the thermal power plant Kolubara A, the overburden from the mine Kolubara and the ash from Kolubara A indicate limited fertility due to low contents of $\mathrm{N}$ and organic $\mathrm{C}$, also contain heavy metals in concentrations between maximal allowable and remediation values $(\mathrm{Ni}, \mathrm{Cu}, \mathrm{Zn})$, are slightly to moderately contaminated. Contents of heavy metals in aboveground biomass of miscanthus is low, making it suitable for use as biofuel. On the opposite side, in whole plants there are significant contents of $\mathrm{Cr}$, $\mathrm{Zn}$ and Ni, mainly in underground organs, indicating phytostabilization potential.

- Main strength: the use of marginal land for the production of bioenergetic crops.

- Weaknesses: low yield.

- Opportunity: use of large marginal land areas with a simultaneous reduced risk of heavy metal transfer to the environment, improving yields with the use of more intensive agri-technical measures.

- Threats: the poorly developed biomass market as well as the lack of interest by land owners for its remediation.
\end{abstract}

Keywords: ash disposal, biomass, heavy metals, coal mine overburden, land reclamation

\section{Introduction}

The Law on the Spatial Plan of the Republic of Serbia from 2010 to 2020 [1] recognizes the exploitation of mineral resources, especially in the Kolubara and Kostolac mining basins, as one of the largest sources of

*e-mail: gordana.drazic@futura.edu.rs soil degradation and pollution. Municipals Obrenovac (thermal power plants (TPP), ash dumps), Lazarevac (surface coal mines, TPP, ash and slag disposal, coal processing), and Kostolac (TPP, open pit coal mines, ash and slag dumps) are classified as the most vulnerable areas ("hot spots") in the Republic of Serbia. The mentioned and similar sites contaminated with certain pollutants require remediation. According to the United States Environmental Protection Agency [2], the process of applying a particular remediation technology 
precedes the identification of pollutants present and the assessment of their impact on human health and the environment. After identifying and assessing the effects of pollutants, a procedure for the treatment or removal of contaminated media is followed. To implement the remediation of contaminated land, a wide range of technologies is used, with the aim being to completely remove the pollutants from the site and/or treat them to a level where they no longer pose a threat to human health and the environment.

Technology that is increasingly used for reclamation of land degraded by mining is phytoremediation. The use of various types of plants directly on contaminated soil results in the removal of pollutants, primarily heavy metals (HM), if they are transported to the above-ground part of the plant that is removed from the site $[3,4]$ in the phytoextraction process, or they remain immobilized in the underground parts of the plant during the phytostabilization process $[5,6]$, The bioconcentration of heavy metals in plant matter depends on the type of heavy metal, soil characteristics, the content of TM in soil and its bioavailability and genetic, physiological and morphological characteristics of the plant. The primary objective of land reclamation degraded by mining and or industrial activities is to reduce the risk to human health, but for such projects to be sustainable from energetic, environmental and economic aspects it is necessary for the plants to be usable in the future [7-10].

Contamination of soil degraded by industrial activities excludes them from the cultivation of crops used for human or animal nutrition, thus the idea of use for the production of energy crops has more and more supporters [11-14]. Recently published results indicate that it is possible for the economically justifiable production of energy crops in the areas of abandoned mines or in the vicinity of active ones $[5,11,15]$. The yields obtained are comparable, although regularly lower, than the average yields obtained on agricultural land [16]. The cultivation of energy crops on arable land should be avoided because it takes the place of food production [17]. Miscanthus giganteus, energy lignocellulosic crop of the $2^{\text {nd }}$ generation, is tolerant to heavy metals (HM) in the substrate and with low fertility requirements [18-20]. On the other hand, this grass's development of aboveground organs (stems and leaves) begins in the spring with maximum yields at the end of the autumn. Aboveground biomass then contains a large amount of water and minerals and is therefore not suitable for combustion. During the autumn and winter, the nutrients are relocated to the underground organs (rhizomes and roots), and cold weather and winds dry up the aboveground biomass, so in the spring the aboveground biomass loses about $30 \%$ but gets quality [21-23]. Leaves that fall during the winter remain as mulch on the plot and lead to soil fertility improvement. Production of miscanthus as energy crops is spreading rapidly in Europe, as well as in the USA and Asia [24-25]. With the growth of areas under this crop, there was a need for a comprehensive environmental impact analysis, primarily on soil quality, the local economy and the development of combustion or pyrolysis technologies. One of the applied methods is SWOT analysis [12, 13]. In the Republic of Serbia, the production of agri-energetic crops has not been sufficiently developed, but during its joining process, the EU is expected to intensify it, so research is indispensable.

In this paper, we investigated the potential of miscanthus production on the soil-degraded activities of the electro power industry Serbia in MB Kolubara (overburden from open pit coal mine and thermal power plant ash and slag disposal) with the aim to analyze the possibilities of sustainable development of the area after closure of the power plant.

\section{Experimental}

\section{Site Description}

Kolubara Mining Basin is the largest coal producer in the Electro Power Industry Serbia (EPS) public enterprise. According to the territorial-administrative division (MB), Kolubara covers parts of four municipalities: Lazarevac, Lajkovac, Ub and Obrenovac in the area of $547,14 \mathrm{~km}^{2}$. It is located about $50 \mathrm{~km}$ southwest of Belgrade and extends to the middle and lower parts of the Kolubara River and its inflow Tamnava and Kladnica from the left and Peštan and Beljanica on the right, as well as the Ub and Turija streams. The east-west axis is $55 \mathrm{~km}$ long and southnorth $15 \mathrm{~km}$. [26]. Production units within Kolubara are: Baroševac Surface Mine branch with five active open pit mines: Field B, Field C, Field D, Tamnava West Field, Veliki Crljeni Field and Tamnava East Field, where coal mining is completed, with future landfills for homogenization of coal; the processing branch with plants for dry separation, carbonated coal (wet separation, dryers and classification, heating, maintenance) and railway transport. At a different level of realization are also the procedures for opening new surface mines: Field E, Field G, Field F and field Radljevo. TPP Kolubara A, the oldest power plant in EPS, located in Veliki Crljeni, has a total installed power of $271 \mathrm{MW}$, with boiler 2 (32 MW) not operating since 1998. In addition to chimneys representing point sources of pollution, ash and slag dumps on the surface area close to 76 ha represent diffuse sources of pollution of water, soil and air. Ash and slag disposal are an open landfill of a large area. Due to unfavorable physical and chemical properties of ash, erosion by wind can occur, especially in adverse meteorological conditions (dry and windy weather). In order to prevent this phenomenon, protection measures are implemented: maintenance of water mirrors, technical and biological reclamation. The surrounding settlements are Veliki Crljeni, Stepojevac, Sokolovo, and Junkovac. There are no protected areas of cultural or natural heritage. 


\section{Soil Analysis}

The samples from four soil types were analyzed: ash from the TPP Kolubara A disposal, arable land in the vicinity of TPP Kolubara (in diameter of up to $2 \mathrm{~km}$ ) at 16 locations, overburden of open pit coal mine where a field experiment with a miscanthus was made and on arable land outside the zone of direct influence of TPP (2 locations) in three seasons starting from 2014. Samples were collected by sampling probe as undisturbed soil samples from ten randomly selected points per sampling area (within a diameter of $3 \mathrm{~m}$, 0-30 cm deep), and were transported in plastics bags as mixed samples of about $1 \mathrm{~kg}$. The soil samples were dried at room temperature and in an oven at $40^{\circ} \mathrm{C}$ before being ground in a mill. The content of organic carbon in the soil samples was determined by redox titration of ferro ammonium sulfate. The organic matter is oxidized potassium dichromate, and the excess of oxidizing agent the titration of the ferrous ammonium sulfate, with ferroin as an indicator. The readily available phosphorus $\left(\mathrm{P}_{2} \mathrm{O}_{5}\right)$ in the soil samples was determined after extraction of sodium bicarbonate spectrophotometrically with ammonium molybdate. Available potassium $\left(\mathrm{K}_{2} \mathrm{O}\right)$ was determined by atomic absorption spectrometry after extraction of sodium chloride. Total nitrogen (N) was determined using the method after Kjeldahl.

The content of heavy metals was determined in an accredited laboratory. Total contents of: Cr (EPA M 218.1: 1978), Ni (EPA M 249.1: 1978), Pb (EPA M 239.2: 1978), Cu (EPA M 220.1: 1978), Zn (EPA M 289.1: 1974) EPA M 213.2: 1978), As (EPA M 206.2: 1978) and Fe (EPA M 236.1: 1978) in soil samples were determined after digestion using nitric acid, hydrogen peroxide and hydrochloric acid using atomic absorption spectrometry. The content of mercury in soil samples is determined after digestion (hydrochloric acid and nitric acid are added, oxidation is carried out with potassium permanganate, excess potassium permanganate is reduced with hydroxylamine hydrochloride, and then stan chloride is added to live into a gaseous state by cold AAS method (EPA M 245.1: 1994) [27].

\section{Field Experiment}

The field experiment was set up on the soil of the Technosol type overburden of the MB Kolubara $\left(44^{\circ} 28^{\prime} 16,41^{\prime \prime} \mathrm{N}, 20^{\circ} 14^{\prime} 59,62^{\prime \prime} \mathrm{E}\right)$ at 2011 . The field experiment was set up in a randomized complete block design with three replications on parcels of $10 \times 10 \mathrm{~m}$, aimed to determinate impacts of fertilizing and canopy density on biomass development and quality. The plot was formed immediately prior to planting in April and fertilized with NPK mineral fertilizer containing $7.5 \mathrm{~kg} / \mathrm{ha} \mathrm{N}, 7.5 \mathrm{~kg} / \mathrm{ha} \mathrm{P}, 7.5 \mathrm{~kg} / \mathrm{ha} \mathrm{K}$, just before the planting. Irrigation was carried out only during the first vegetation. Mechanical weed control was carried out as needed during the first and second vegetation seasons. Rhizomes of miscanthus, Miscanthus giganteus (Greef et Deu), a size of 3-5 buds, were sown with a distance of $1 \mathrm{~m}$ between rows and $0,5 \mathrm{~m}$ in row, corresponding to a plant density of $20000 \mathrm{pcs} / \mathrm{ha}$. Aboveground biomass was collected manually in early harvest 2014, 2015 and 2016. Samples consisting of 10 randomly selected canes per experimental plot were dried in the air and then in the oven dryer for determining dry mass (DM).

\section{Pot Experiment}

A vessel of $10 \mathrm{~L}$ volume was filled with ash from the TPP Kolubara disposal, overburden and arable soil, three vessels each. In April, rhizomes of miscanthus were planted $(1$ per pot). The fertilization was carried out as in the field experiment, and the watering was carried out $2 \times$ monthly for the next 5 months. By the end of September, the total biomass was collected (the overhead part consisting of stems and leaves and an underground part consisting of rhizomes and roots). The underground parts were carefully washed before being analyzed for TM content. TM content in plant material was determined by AAS method after wet digestion [28].

\section{Statistical Processing}

Statistical analyzes were performed using SPSS version 13.0 (SPSS Inc., Chicago, USA).

\section{SWOT}

The strengths, weaknesses, opportunities and threats (SWOT) analysis was applied to explore the environmental and economic impacts of miscanthus production on land degraded by the power industry in MB Kolubara, Republic of Serbia [13].

\section{Results and Discussion}

By choosing and applying the most appropriate soil remediation techniques degraded by industrial activities, the process of environmental remediation and the protection of natural resources is established in a completely natural way. Selected and applied ecoremediation approaches are typically multi-purpose, long-term and socially beneficial because they connect the environment with economic and social development [8]. We have assumed that in degraded locations belonging to EPS, it is an acceptable and sustainable approach to the cultivation of agri-energy crops, primarily Miscanthus gigantheus. In order to investigate the hypothesis, research was carried out in 3 steps: 1) the characteristics of the soil were investigated in the zone of influence of the TPP Kolubara A, the overburden from the MB Kolubara and the ash from the TPP Kolubara; 2) the possibility of producing Miscanthus on these substrates and its remediation potential in reducing the risk of heavy metals and 3) the SWOT analysis, which 
Table 1. The content of heavy metals in the soil in comparison with the maximal allowed concentrations (MAC), remediation value (RV).

\begin{tabular}{|c|c|c|c|c|c|c|c|c|}
\hline & \multirow{2}{*}{ Unit } & \multicolumn{3}{|c|}{ Soil } & \multirow{2}{*}{ Ash } & \multirow{2}{*}{ Soil control } & \multirow{2}{*}{ Overburden } & \multirow{2}{*}{$\begin{array}{c}\mathrm{MAC} / \mathrm{RV} \\
{[32]}\end{array}$} \\
\hline & & Average & $\min$ & $\max$ & & & & \\
\hline $\mathrm{Cr}$ & $\mathrm{mg} / \mathrm{kg}$ & 29.99 & 18.44 & 75.32 & 25.58 & 19.08 & 58.75 & $100 / 380$ \\
\hline $\mathrm{Ni}$ & $\mathrm{mg} / \mathrm{kg}$ & 37.31 & 31.88 & 48.89 & 48.37 & 28.88 & 78.65 & $35 / 210$ \\
\hline $\mathrm{Pb}$ & $\mathrm{mg} / \mathrm{kg}$ & 42.79 & 28.61 & 49.08 & 28.68 & 36.68 & 15.14 & $85 / 530$ \\
\hline $\mathrm{Cu}$ & $\mathrm{mg} / \mathrm{kg}$ & 25.24 & 16.86 & 31.76 & 90.75 & 27.85 & 19.32 & $36 / 190$ \\
\hline $\mathrm{Zn}$ & $\mathrm{mg} / \mathrm{kg}$ & 48.28 & 39.51 & 58.08 & 189.1 & 43.04 & 48.65 & $140 / 720$ \\
\hline $\mathrm{Cd}$ & $\mathrm{mg} / \mathrm{kg}$ & 0.26 & 0.2 & 0.32 & 0.23 & 0.22 & 0.71 & $0.8 / 12$ \\
\hline $\mathrm{Hg}$ & $\mathrm{mg} / \mathrm{kg}$ & 0.03 & 0.02 & 0.04 & 0.04 & 0.025 & - & $0.3 / 10$ \\
\hline B & $\mathrm{mg} / \mathrm{kg}$ & 43.72 & 27.75 & 62.18 & 57.61 & 55.745 & - & - \\
\hline As & $\mathrm{mg} / \mathrm{kg}$ & 14.60 & 8.86 & 19.12 & 7.75 & 10.72 & 4.59 & $29 / 55$ \\
\hline $\mathrm{Fe}$ & $\%$ & 2.17 & 1.86 & 2.42 & 1.87 & 2.02 & 1.94 & - \\
\hline
\end{tabular}

should point to the sustainability of such an approach, was examined.

\section{Characteristics of Substrates}

The agrochemical properties of the soil at the investigated sites (arable land in the zone of influence of TPP Kolubara A, control soil outside the impact zone, ash and sludge from the TPP Kolubara A disposal and overburden from open pit coal mine MB Kolubara) indicate their limited fertility as they contain a little N (0.10\% with overburden, $0.12-0.14 \%$. in ash, $0.12-0.26 \%$ in soil) as well as organic $\mathrm{C}(2.64 \%$ in ash, $0.64 \%$ in overburden and 2.12 do $5.06 \%$ in soil) $[20,29]$. In all investigated soils $\mathrm{pH}$ is close to neutral (6.40-7.89). According to results from Poland, it was found that to obtain high yields Miscanthus giganteus does not need cultivation on the best agricultural soils. This plant has the best yields on soils of average quality, not too heavy [30]. In Serbia, the highest yields were achieved on Gleysol [29] and carbonate chernozem [31].

The total content of TM in the tested soil samples is compared with the regulations of the Republic of Serbia (Table 1). Content of total $\mathrm{Cr}, \mathrm{Pb}, \mathrm{Cd}, \mathrm{Hg}$, and As in all tested samples is significantly lower than the maximal allowed concentrations (MAC). Ni content was higher than the MAC in overburden, $50 \%$ of soil under influence of TPP Kolubara and ash samples [32]. $\mathrm{Cu}$ and $\mathrm{Zn}$ contents exceeds MAC in ash but found that values do not exceed remediation value (RV). According to the content of TM, the tested soil belongs to a slightly to moderately contaminated area. However, such land is not recommended for the production of food for people or animals due to the possibility of entering TM present in the food chain. For the same reason, crops that do not eat wild animals [33] should be cultivated on such substrates. Therefore, miscanthus is chosen as a highyield crop.

Table 2. Heavy metal contents in miscanthus $(\mathrm{mg} / \mathrm{kg}) .{ }^{*}$ pot experiment $1^{\text {st }}$ growing season; $* *$ field experiment $5^{\text {th }}$ growing season, overburden. ND: not detected; ${ }^{1}$ according to [43], ${ }^{2}$ according to [44].

\begin{tabular}{|c|c|c|c|c|c|c|}
\hline & \multicolumn{3}{|c|}{ Whole plant* } & \multirow{2}{*}{$\begin{array}{l}\text { Aboverground } \\
\text { Biomass** }\end{array}$} & \multirow{2}{*}{ Plants Average $^{1}$} & \multirow{2}{*}{ Plants toxic ${ }^{2}$} \\
\hline & Ash & Soil & Overburden & & & \\
\hline $\mathrm{Cr}$ & $45.10 \pm 7.44$ & $129.9 \pm 23.88$ & $72.64 \pm 8.66$ & $3.62 \pm 0.26$ & $0.2-1$ & $1-2$ \\
\hline $\mathrm{Ni}$ & $15.62 \pm 2.18 \mathrm{a}$ & $44.92 \pm 7.23$ & $20.82 \pm 3.02 \mathrm{a}$ & $10.74 \pm 2.06$ & 1 & $20-30$ \\
\hline $\mathrm{Pb}$ & $6.82 \pm 0.89 b$ & $19.51 \pm 2.24$ & $8.17 \pm 1.47 \mathrm{~b}$ & $4.14 \pm 0.34$ & $1-13$ & $10-20$ \\
\hline $\mathrm{Cu}$ & $12.17 \pm 2.02 \mathrm{c}$ & $23.26 \pm 1,78$ & $11.52 \pm 2.26 \mathrm{c}$ & $2.51 \pm 0.27$ & $4-15$ & $15-20$ \\
\hline $\mathrm{Zn}$ & $23.35 \pm 4.12 \mathrm{~d}$ & $70.42 \pm 8.56$ & $24.34 \pm 3.66 \mathrm{~d}$ & $40.2 \pm 0.17$ & $8-100$ & $150-200$ \\
\hline $\mathrm{Cd}$ & $0.54 \pm 0.04$ & $1.10 \pm 0.15 \mathrm{e}$ & $1.11 \pm 0.32 \mathrm{e}$ & $0.22 \pm 0.06$ & $0.1-2.4$ & $5-10$ \\
\hline $\mathrm{Hg}$ & ND & ND & ND & ND & $0.005-0.02$ & $1-3$ \\
\hline As & $4.02 \pm 0.66$ & $5.41 \pm 0.72$ & $2.34 \pm 0.43$ & $0.82 \pm 0.11$ & $0.02-7$ & 20 \\
\hline
\end{tabular}


Table 3. SWOT analysis of miscanthus production on land degraded by power industry.

\begin{tabular}{|c|c|}
\hline Strengths & Weaknesses \\
\hline $\begin{array}{l}\text { Favorable climatic conditions, the corresponding altitude for miscanthus } \\
\text { production } \\
\text { Land slightly to moderately polluted TM, } \\
\text { Large areas with relatively fertile soil } \\
\text { hus cultivation } \\
\text { Improving agro-chemical characteristics of the soil / organic C after miscant- } \\
\text { Low content of heavy metals in the aboveground biomass of miscanthus } \\
\text { Available infrastructure (roads, biomass heating plants) } \\
\text { Avalilable workers and agricultural machinery } \\
\text { The whole process of phytoremediation is natural, guided by solar energy, low } \\
\text { cost applications }\end{array}$ & $\begin{array}{l}\text { The need for watering and weed control during the } \\
\text { first vegetation } \\
\text { Low yields with minimal investment and agricul- } \\
\text { tural measurements } \\
\text { Insufficient education community } \\
\text { A slow and lengthy process of phytoremediation }\end{array}$ \\
\hline Opportunities & Threats \\
\hline $\begin{array}{c}\text { The potential for sustainable production of energy crops on degraded land } \\
\text { Climate change adaptation by } \mathrm{C} \text { sequencing during canopy duration and low } \\
\text { emissions of greenhouse gases during combustion } \\
\text { Employing local workers after the closure of the thermo power plant } \\
\text { Bio-rational use of marginal lands } \\
\text { Use of sludge for yield improvement on ash and overburden } \\
\text { Increase the ecosystem value of landscapes }\end{array}$ & $\begin{array}{l}\text { Underdeveloped biomass market } \\
\text { Low interest of local communities for innovative } \\
\text { solutions } \\
\text { Increased costs of production of miscanthus bio- } \\
\text { mass with a complete cultural practice } \\
\text { Insufficient interest land owners for the remedia- } \\
\text { tion }\end{array}$ \\
\hline
\end{tabular}

\section{Heavy Metals in Miscanthus}

The production of a miscanthus on degraded or marginal soil should simultaneously provide land remediation and biomass production with satisfactory quality and yield [19].

$\mathrm{Cr}$ accumulates in underground organs and only a small part transports to an aboveground biomass, where it reaches a concentration that can be phytotoxic, is not correlated with the contents in the substrate. A significant amount of $\mathrm{Ni}$ is transported to the aboveground but does not reach phytotoxic concentrations, this also applies to $\mathrm{Pb}, \mathrm{Cd}$ and As. There is no significant correlation with the content in the substrate except for As (Table 2).

In combustion of biomass miscanthus, some TM can be volatilized, primarily $\mathrm{Cd}, \mathrm{Pb}$ and $\mathrm{Zn}$ [34], so it is important that their content in the aboveground part be as low as possible. The TM content in the miscanthus biomass grown on non-contaminated soil is about $0.2 \mathrm{mg} / \mathrm{kg}$ for As, $0.1 \mathrm{mg} / \mathrm{kg}$ for Cd, $2 \mathrm{mg} / \mathrm{kg}$ for $\mathrm{Cu}, 0.03 \mathrm{mg} / \mathrm{kg}$ for $\mathrm{Hg}, 2 \mathrm{mg} / \mathrm{kg}$ for $\mathrm{Ni}$ and $\mathrm{Pb}$, and $10 \mathrm{mg} / \mathrm{kg}$ for $\mathrm{Zn} \mathrm{[34].} \mathrm{In} \mathrm{the} \mathrm{aboveground} \mathrm{biomass}$ of the miscanthus grown on soil contaminated TM content TM depends significantly on the genotype (species), the age of the canopy (exposure duration), and the type of substrate (most $\mathrm{pH}$, content of organic matter and TM content) [35]. The results for all tested $\mathrm{TM}$ are found in a range of published research: $\mathrm{Cr}$ content $0.32-51 \mathrm{mg} / \mathrm{kg} ; \mathrm{Pb}$ content $0.09 \mathrm{mg} / \mathrm{kg}$ in Miscanthus gigantheus on sewage sludge to $324 \mathrm{mg} / \mathrm{kg}$ and Miscanthus floridulus on mine tailing containing $2500 \mathrm{mg} / \mathrm{kg}$; $\mathrm{Cd} 0.1-4.3 \mathrm{mg} / \mathrm{kg} ; \mathrm{Cu} 1.8-7.5 \mathrm{mg} / \mathrm{kg}$ on arable soil; Zn $17 \mathrm{mg} / \mathrm{kg}$ Miscanthus gigantheus on soil to $1163 \mathrm{mg} / \mathrm{kg}$ on mine tailing containing $9375 \mathrm{mg} / \mathrm{kg}$ [33].

\section{SWOT Analysis}

The use of land as a practically non-renewable resource is important not only for the functioning of the ecosystem but also for the realization of the concept of sustainable development. Therefore, use of land degraded by industrial activities is increasingly present in sustainable development programs around the world $[7,14]$. At least three causes determine the importance of eco-remediation of the brownfield location: a) the growth of knowledge of secondary environmental impacts (climate change, energy aspects, waste production); b) stakeholder requests for economically viable remediation using "green" technologies and c) institutional pressure to promote sustainability. In analyzing the effects of eco-techniques in the revitalization of brownfield sites, cost-benefit analysis [36] and LCA analysis [37] were most often used. In recent years, SWOT analysis [12] has been increasingly used to help decision-makers in prioritizing implementation of remediation plans. When analyzing environmental, economic and sociological trends, most authors are based on literature data, giving preference to programs that simultaneously perform land remediation degraded by industrial activities using an environmentally friendly technology with the production of crops that can later be used in a sustainable manner. When it comes to marginal lands that are loaded, to a lesser or greater extent, heavy metals are preferred to energy crops in relation to crops used for human or animal nutrition in order to reduce the risk to their health. At the same time, in this way the use of agricultural land for the production of energy crops is avoided, which is in line with the requirements of the EU [37].

The brownfield location eco remediation should stimulate the economy of the community, preserve green 
areas and provide an opportunity for environmental restoration. The purpose of this kind of eco remediation is to restore and establish active use of resources from these areas, increase employment, mitigate the risk to public health and reduce the pressure on natural resources, which significantly improves community image.

The basis for SWOT analysis in this paper used the empirical results obtained in pot trials and field experiment at the investigated area [20, 23, 29, 38]. In analyzing the strengths (S), weaknesses (W), opportunities (O) and threats $(\mathrm{T})$, the environmental aspects of the production of miscanthus at the locations of MB Kolubara were considered (Table 3). The yield of the aboveground biomass in the period after the 3 rd year on the overburden is about 5 t/ha [29] with a density of 2 rhizomes $/ \mathrm{m}^{2}$, on the ash from disposal of the TPP average $1.81 \mathrm{t} / \mathrm{ha}$ in the third and the fourth year and early spring harvest (min 0.39 , max 5.88), on the reference soil an average of $11.73 \mathrm{t} / \mathrm{ha}(\mathrm{min} 3.83$, max 23.70), where the yield varied substantially from the year of production and planting density [31]. The achieved yields are ranked at various locations across Europe [21] and the United States at sites of reclaimed mines [11]. The yield of the miscanthus depends on the climatic and edaphic factor of the site, the miscanthus genotype, and the applied agrotechnical measures, and the comparison of the results is difficult because they were obtained under different experimental conditions. For further consideration, $12 \mathrm{t} / \mathrm{ha}$ for arable land, $5 \mathrm{t} / \mathrm{ha}$ for overburden and 1,80 t/ha for ash were used. These values refer to early spring harvest, which in most cases is $30 \%$ less than the maximal yield at the end of the growing period [22], and the difference consists of rejected leaves that remain on the plot as litter. This biomass has at least two environmental aspects: a mulch that suppresses the development of weeds, so that it is not necessary to remove them after the second vegetative season [38] and the content of $\mathrm{C}$ about $46 \%$ which, depending on the microbiological activity of the soil, can contribute to increasing its fertility over the course of several years and contribute to reducing the production of greenhouse gases [39]. When considering the life cycle as a whole, miscanthus has significant advantages compared to coal and natural gas from the aspect of the $\mathrm{CO}_{2}$ balance per kWh-generated energy, even when combustion in conventional steam turbine power plants and can make a significant contribution to climate change mitigation (strengths) [40].

In our case, relatively low yields (weaknesses) determine the content of $\mathrm{C}$ in the litter layer at $12 \mathrm{t} / \mathrm{ha} \times 0.3 \times 0.46=1.66 \mathrm{t} / \mathrm{ha} /$ year for the arable land; $5 \times 0.3 \times 0.46=0.69 \mathrm{tC} / \mathrm{ha} /$ year for overburden and $1.2 \times 0.3 \times 0.46=0.17 \mathrm{t} / \mathrm{ha} /$ year for ash. At the same time, in an aboveground biomass composed of steam with $44 \% \mathrm{C}$, it is removed from the atmosphere $12 \mathrm{t} /$ ha $\times 0.44=5.28 \mathrm{t} /$ year for the arable land; $5 \times 0.44=2.2 \mathrm{t} / \mathrm{ha}$ year on overburden and $1.2 \times 0.44=0.53 \mathrm{t} / \mathrm{ha} /$ year on ash. Underground biomass consists of rhizomes and roots, of which about $90 \%$ are in a layer of $30 \mathrm{~cm}$ of soil. According to published data [18], the biomass of rhizomes is $61 \%$ of the aboveground biomass and contains $45.7 \% \mathrm{C}$; the root biomass is $16 \%$ of the aboveground biomass and contains $41 \% \mathrm{C}$. If the application of this relation and the yields achieved in MB Kolubara is obtained, content of $\mathrm{C}$ for the rhizomes: $3.35 \mathrm{t} / \mathrm{ha}$ on the soil; $1.39 \mathrm{t} / \mathrm{ha}$ for overburden and $0.33 \mathrm{t} / \mathrm{ha}$ for ash, i.e., for the root of $0.79 \mathrm{t} / \mathrm{ha}$ for arable soil, $0.33 \mathrm{t} / \mathrm{ha}$ for overburden and $0.08 \mathrm{t} / \mathrm{ha}$ for ash. The microbial community and its activity is low in the overburden tailings because the canopy is established immediately upon the technical reclamation of the material that does not contain the surface layer of the soil, and even lower in the ash, which is freshly sterile (threats). This can be overcome by more intensive agri-technical measures on overburden dumps and ash disposal, with the application of fresh manure or sewage sludge from the water treatment system located in MB Kolubara (opportunity).

The main costs of remediation of heavy metals include the degree of pollution, the level of environmental standards that must be met, the local state of the polluted site and the applied technology [19]. The link between remuneration and invested funds depends on both national regulations and their application. In some cases these costs are so high that land owners give up remediation [9]. This is especially the case in MB Kolubara, when the degree of pollution is low- to moderately contaminated soil, i.e., below the MDK and/or the remediation values prescribed by regulations when phytoremediation appears as a possible solution, given the low investment. The production of bioenergy crops on contaminated land can be an economic incentive for the phytoremediation of these sites, while providing land that does not compete for food production, reducing the use of fossil fuels, creating employment opportunities and reducing the risk of spreading pollutants from low or moderate contaminated sites [10] (opportunities).

Investments in the plantation of miscanthus production is the highest in the first year of canopy establishment and amounts in EUR: for raw materials $0,15 /$ rhizome $\times 10000$ pieces $/$ ha $=1500$, fertilizer $0.40 / \mathrm{kg}$ × $150 \mathrm{~kg} / \mathrm{ha}=60$, herbicide 60.2 ; for conventional soil processing (plowing, seedbed preparation, fertilizing, planting, intercropping) 195 or total of $1815 \mathrm{EUR} /$ ha of direct costs. In the first year after founding, yields are small and the harvest does not make sense; in the second year yields were about half of yields in the coming years (from the third to the $20^{\text {th }}$ ) [29, 41, 42], when the costs only apply to the harvest and amounts: for mechanical harvest by forage harvesters 93, for transport up to $20 \mathrm{~km} 40$. Costs are given roughly on the basis of 2017 prices. Based on the price of $50 \mathrm{EUR} / \mathrm{t}$ for the chopping and realized yield, direct profit is for arable land $50 \times 12=600 \mathrm{EUR} / \mathrm{ha} /$ year; for overburden 50 × $5=250$ EUR/ha/year and for ash dumps 
$50 \times 1.2=60 \mathrm{EUR} / \mathrm{ha} / \mathrm{year}$. In the case of $\mathrm{MB}$ Kolubara only on arable soil can it be expected to be an economically profitable investment in the miscanthus plantation on the basis of direct benefits (threats for overburden and ash dumps). The application of more intensive agri-technical measures can increase yields on the overburden tailings, and possibly at ash dumps to $10 \mathrm{t} / \mathrm{ha}$, which is considered to be the limit of costeffectiveness (opportunity). However, the value of ecosystems that are significantly increased by the immobilization of heavy metals in the substrate, the prevention of erosion by wind and the significant reduction in the production of greenhouse effect gases during combustion of biomass in relation to lignite are not counted here. Also, the use of biomass after phytoremediation is limited due to the lack of knowledge about emissions and transmission of pollutants, especially for heavy metals [2] (threats).

\section{Conclusions}

The potentials of using soil degraded by industrial activities in MB Kolubara in the Republic of Serbia for the establishment of plantation of bioenergetic crop Miscanthus giganteus are analyzed. Arable land, overburden from the open pit coal mine and ash and slag disposal from TPP Kolubara A contain low to medium concentrations of heavy metals $\mathrm{Cr}, \mathrm{Ni}, \mathrm{Pb}, \mathrm{Cu}$, $\mathrm{Zn}, \mathrm{Cd}, \mathrm{B}$ and $\mathrm{As}$, while the content of $\mathrm{Hg}$ is low, so they are suitable for phytoremediation for the purpose of immobilization or removal of heavy metals. Measured content of heavy metals in miscanthus plants is common, i.e., miscanthus is not a heavy metal accumulator. The relatively low content of heavy metals in the aboveground biomass is not suitable for the extraction of TM from the substrate but is suitable for the combustion of biomass in thermal power or heating plants.

The production of biomass miscanthus is possible on all three investigated substrates, but yields vary considerably in the function of substrates, weather conditions and applied agri-technical measures with average values of $12 \mathrm{t} / \mathrm{ha} /$ year on arable soil, $5 \mathrm{t} / \mathrm{ha} /$ year on overburden and $1.2 \mathrm{t} / \mathrm{ha} /$ year on the ash. Strengths: the use of marginal land for the production of bioenergetic crops was noted, which excludes food production competitiveness, the possibility of using infrastructures, and the contribution to reducing the greenhouse gas emissions. The basic weaknesses are relatively low yields, especially on the ash and slow phytoremediation process. Opportunities are the use of large marginal land areas with a simultaneous reduced risk of heavy metal transfer to the environment, the production of economically significant biomass yields with the use of more intensive agri-technical measures, including sewage sludge applications from the local wastewater treatment plant. The poorly developed biomass market as well as the lack of interest by landowners for its remediation are the basic threats.
Further studies of the impact of multi-annual miscanthus production on the tested land are necessary in order to identify other potential benefits such as increasing fertility of the soil by increasing microbial activity that would contribute to the process of phytoremediation (stabilize larger quantities of heavy metals) and increase the yield of agri-energy crops.

\section{Acknowledgements}

This study was supported by the Ministry of Education, Science and Technological Development of the Republic of Serbia through project TR 31078 "Ecoremediation of degraded areas by agri-energy crops production."

\section{Conflict of Interest}

The authors declare no conflict of interest.

\section{References}

1. REPUBLIC AGENCY FOR SPATIAL PLANNING OF THE REPUBLIC OF SERBIA. The Law on the Spatial Plan of the Republic of Serbia from 2010 to 2020. Official Gazette of the Republic of Serbia, 88, 2010.

2. US ENVIRONMENTAL PROTECTION AGENCY. Introduction to Phytoremediation, Cincinnati, $\mathrm{OH}$ : National Risk Management Research Laboratory, Office of Research and Development, 2000.

3. HAZANT A., KHAN E., SAJAD M.A. Phytoremediation of heavy metals - concept and applications. Chemosphere 91, 869, 2013.

4. BARCELO J., POSCHENRIEDER C. Phytoremediation: principles and perspectives. Contributions to Science 2 (3), 333, 2003.

5. CETINKAYA G., SOZEN N. Plant Species Potentially Useful in the Phyto stabilization Process for the Abandoned CMC Mining Site in Northern Cyprus. International Journal of Phytoremediation 13 (7), 681, 2011.

6. RADZIEMSKA M., VAVERKOVÁ M.D., BARYŁA A. Phyto stabilization - Management Strategy for Stabilizing Trace Elements in Contaminated Soils. International Journal of Environmental Research and Public Health 14, 958, 2017.

7. FERBER U., GRIMSKI D. Brownfields and redevelopment of urban areas, Austrian Federal Environment Agency, Austria, on behalf of CLARINET, 1, 2002.

8. HOU D., AL-TABBAA A. Sustainability: A new imperative in contaminated land remediation. Environmental Science and Policy 39, 25, 2014.

9. DICKINSON N.M., MACKAY J.M., GOODMAN A., PUTWAIN P. Planting trees on contaminated soils: Issues and guidelines. Land Contamination and Reclamation 41, 87, 2000.

10. LICHT L.A., ISEBRANDS J.G. Linking phytoremediated pollutant removal to biomass economic opportunities. Biomass Bioenergy 28, 203, 2005.

11. SKOUSEN J., KEENE T., MARRA M., GUTTA B. Reclamation of mined land with switchgrass, miscanthus, 
and Arundo for biofuel production. Journal American Society of Mining and Reclamation 2 (1) 177, 2013.

12. GOMES H.I. Phytoremediation for bioenergy: challenges and opportunities. Environmental Technology Reviews $\mathbf{1}$ (1), 59, 2012.

13. LIUA T.T., MCCONKEYA B.G., MAB Z.Y., LIUD Z.G., LIB X., CHENGB L.L. Strengths, Weaknesses, Opportunities and Threats Analysis of Bioenergy Production on Marginal Land. Energy Procedia 5, 2378, 2011.

14. THORNTON G., FRANZ M., EDWARDS D., PAHLEN G., NTHANAIL P. The Challenge of sustainability: initiatives for brownfield regeneration in Europe. Environmental Science and Policy 10, 116, 2007.

15. GELFAND I., SAHAJPAL R., ZHANG X., IZAURRALDE R.C., GROSS K.L., ROBERTSON P. Sustainable bioenergy production from marginal lands in the US Midwest. Nature 493, 514, 2013.

16. JEŻOWSKI S., MOS M., BUCKBY S., CERAZYWALISZEWSKA J., OWCZARZAK W., MOCEK A., KACZMAREK Z., MCCALMONT J.P. Establishment, Growth, and Yield Potential of the Perennial Grass Miscanthus $\times$ Giganteus on Degraded Coal Mine Soils. Frontiers in Plant Science 8: 726, 2017.

17. EUROPEAN ENVIRONMENTAL AGENCY. Report 6/2013, EU Bioenergy Potential from a Resource-efficiency Perspective, Publications Office of the European Union: Luxembourg, 60, 2013.

18. DOHLEMAN F.G., HEATON E.A., ARUNDALE R.A., LONG S.P. Seasonal dynamics of above- and belowground biomass and nitrogen partitioning in Miscanthus $x$ giganteus and Panicum virgatum across three growing seasons. GCB Bioenergy 4, 53, 2012.

19. PIDLISNYUK V., STEFANOVSKA T., LEWIS E.E., ERICKSON L.E., DAVIS, L.C. Miscanthus as a Productive Biofuel Crop for Phytoremediation. Critical Reviews in Plant Sciences 33 (1), 1, 2014.

20. DRAŽIĆ G., ARANĐELOVIĆ M., MILOVANOVIĆ J., JUREKOVÁ Z., MARIŠOVÁ E. Potentials for agro-energy crops production: example of miscanthus cultivation in Serbia. Acta Regionalia et Environmentalica 2, 29, 2015.

21. JEŻOVSKI S. Yield traits of six clones of Miscanthus in the first 3 years following planting in Poland. Industrial Crops and Products 27, 65, 2008.

22. LEWANDOWSKI I., HEINZ A. Delayed harvest of Miscanthus - influences on biomass quantity and quality and environmental impacts of energy production. European Journal of Agronomy 19, 45, 2003.

23. MILOVANOVIĆ J., DRAŽIĆ G., IKANOVIĆ J., JUREKOVA Z., RAJKOVIĆ S. Sustainable production of biomass through Miscanthus giganteus plantation development. Annals of Faculty Engineering Hunedoara International Journal of Engineering 10, 79, 2012.

24. FARRAR K., HEATON E.A., TRINDADE L.M. Editorial: Optimizing Miscanthus for the Sustainable Bioeconomy: From Genes to Products. Frontiers in Plant Science 9, 878, 2018.

25. LIU W., SANG T. Potential productivity of the Miscanthus energy crop in the Loess Plateau of China under climate change. Environmental Research Letters 8 (4), 044003, 2013.

26. REPUBLIC AGENCY FOR SPATIAL PLANNING OF THE REPUBLIC OF SERBIA. Spatial Plan for the Republic of Serbia, Mining basins. Available online: http:// www.rapp.gov.rs/en-GB/mining-basins/cid296/index/ (accessed on 2704 2018)
27. INSTITUT MOL. Checking the impact ash and slag dumps TPP "Kolubara A" on the land in 2013, report I 661/13, 2013. [in Serbian]

28. DRAŽIĆ G., MILOVANOVIĆ J., STEFANOVIĆ S., PETRIĆ I. Potential of Miscanthus $\times$ giganteus for heavy metals removing from Industrial deposol. Acta Regionalia et Environmentalica 14 (2), 56, 2018.

29. DRAŽIĆ G., MILOVANOVIĆ J., IKANOVIĆ J., PETRIĆ I. Influence of fertilization on Miscanthus $\times$ giganteus (Greef et Deu) yield and biomass traits in three experiments in Serbia. Plant Soil and Environment 63, 189, 2017.

30. MATYKA M., KUŚ J. Influence of Soil Quality for Yielding and Biometric Features of Miscanthus $\mathrm{x}$ Giganteus. Polish Journal of Environmental Studies 25 (1), 213, 2016.

31. DŽELETOVIĆ Ž., MIHAILOVIĆ N., ZIVANOVIĆ I., PIVIĆ R., GLIŠIĆ I., SIMIĆ A. Phytostabilization of power plant ash deposits by bioenergy crop Miscanthus X giganteus. Ekologica 22 (78), 187, 2015 [In Serbian].

32. REPUBLIC OF SERBIA. Regulation on the program quality monitoring system of land, indicators for assessing the risk of land degradation and methodology for making remediation programs. Official Gazette of RS 88, 2010.

33. NSANGANWIMANA F., POURRUT B., MENCH M., DOUAY F. Suitability of Miscanthus species for managing inorganic and organic contaminated land and restoring ecosystem services. A review. Journal of Environmental Management 143, 123, 2014.

34. OBERNBERGER I., BRUNNER T., BARNTHALER G. Chemical properties of solid biofuels - significance and impact. Biomass Bioenergy 30, 973, 2006.

35. BOSIACKI M. Influence of increasing nickel content in soil on Miscanthus $\times$ giganteus Greef and Deu. Yielding and on the content of nickel in above-ground biomass. Archives of Environmental Protection 41 (1), 72, 2015.

36. RODIAS E., BERRUTO R., BOCHTIS D., BUSATO P., SOPEGNO A. A Computational Tool for Comparative Energy Cost Analysis of Multiple-Crop Production Systems, Energies 10, 831, 2017.

37. MORAIS S.A., DELERUE-MATOS C. A. Perspective on LCA application in site remediation services: critical review of challenges. Journal of Hazardous Materials 175, $12,2010$.

38. STEFANOVIĆ S., KOSTIĆ M., MILOŠEVIĆ D., DRAŽIĆ G. The influence of weed vegetation on the yield of miscanthus (Miscanthus $x$ giganteus) on tailings RB Kolubara Tamnava East. Ekologica 23, 106, 2016 [In Serbian].

39. LAI R., ARCA P., LAGOMARSINO A., CAPPAI C., SEDDAIU G., DEMURTAS C.E., ROGGERO P.P. Manure fertilization increases soil respiration and creates a negative carbon budget in a Mediterranean maize (Zea mays L.) - based cropping system. CATENA 151, 202, 2017.

40. ROBERTSON A.D., WHITAKER J., MORRISON R., CHRISTIAN A., DAVIES C.A., SMITH P., MCNAMARA N.P. A Miscanthus plantation can be carbon neutral without increasing soil carbon stocks. GCB Bioenergy $\mathbf{9}$, 645, 2017.

41. DRAŽIĆ G., MILOVANOVIĆ J., ARANDJELOVIĆ M. Biomass as a driving force for rural development miscanthus best practices. Agriculture and Forestry 60 (2), $115,2014$. 
42. MAKSIMOVIĆ J., PIVIĆ R., STANOJKOVIĆ-SEBIĆ A., VUČIĆ-KIŠGECI M., KRESOVIĆ B., DINIĆ Z., GLAMOČLIJA Đ. Planting density impact on weed infestation and the yield of Miscanthus grown on two soil types. Plant Soil and Environment 62, 384, 2016.
43. ACKOVA D.G. Heavy metals and their general toxicity on plants. Plant Science Today 5 (1), 14, 2018.

44. NAGAJYOTI P.C., LEE K.D., SREEKANTH T.V.M. Heavy metals, occurrence and toxicity for plants: a review. Environmental Chemistry Letters 8 (3), 199, 2010. 